\title{
Readiness of Prospective Home Science Teachers for Teaching Alternative Agriculture Topics in Design and Technology Subjects
}

\author{
Rukkumani a/p Sinnatamby, Enio Kang Binti Mohd. Sufian Kang* \\ Department of Science and Technical Education, Faculty of Educational Studies, Universiti Putra Malaysia, Malaysia
}

Received May 29, 2021; Revised July 3, 2021; Accepted August 22, 2021

\section{Cite This Paper in the following Citation Styles}

(a): [1] Rukkumani a/p Sinnatamby, Enio Kang Binti Mohd. Sufian Kang, " Readiness of Prospective Home Science Teachers for Teaching Alternative Agriculture Topics in Design and Technology Subjects, "Universal Journal of Educational Research, Vol. 9, No. 9, pp. 1641 - 1648, 2021. DOI: 10.13189/ujer.2021.090904.

(b): Rukkumani a/p Sinnatamby, Enio Kang Binti Mohd. Sufian Kang (2021). Readiness of Prospective Home Science Teachers for Teaching Alternative Agriculture Topics in Design and Technology Subjects. Universal Journal of Educational Research, 9(9), 1641 - 1648. DOI: 10.13189/ujer.2021.090904.

Copyright $\bigcirc 2021$ by authors, all rights reserved. Authors agree that this article remains permanently open access under the terms of the Creative Commons Attribution License 4.0 International License

\begin{abstract}
The purpose of this study is to identify the level of readiness of future home science teachers in teaching alternative agricultural topics in design and technology subjects. Aspects of readiness were examined to identify the level of knowledge, skill, attitude, and exposure of home science teachers to teaching alternative agricultural topics in design and technology subjects. Data collection was conducted using questionnaires and respondents for this study involved 77 Home Science Education students consisting of 36 students in Year 3 and 41 students in Year 4 who sit for the Agriculture and Human and Practical Teaching of Agricultural Science courses. The questionnaire consisted of 5 sections comprising respondents' background, knowledge, skills, attitudes, and exposure to the topic. The reliability coefficient of this study was $\alpha=0.81$. The data were analyzed using Statistical Package for Social Sciences (SPSS) version 25.0 to obtain the frequency, percentage, mean and standard deviation values. The findings showed that Bachelor of Home Science Education students had a moderate level of readiness $($ mean $=2.71)$ towards teaching alternative agricultural topics in design and technology subjects in terms of knowledge level (mean = $1.86)$, skill level $($ mean $=3.34)$, attitude $($ mean $=3.78)$ and level of exposure (mean $=4.72$ ). Some suggestions have been made to increase the readiness of home science teachers for teaching alternative agricultural topics, so that all future teachers are prepared to master the subjects that
\end{abstract}

will be taught, especially in the areas of knowledge so that they will not miss out and be able to implement teaching and learning more effectively.

Keywords Agricultural Education, Home Science Education, Readiness, Skill, Teaching, Technical

\section{Introduction}

Education is the most important asset in achieving national progress in the future. As stated in the national philosophy of education, with education, society will be educated in a balanced and harmonious manner intellectually, spiritually, emotionally and physically based on faith and obedience to God. In examining the world of education, teachers are among the most important groups in the formation of human beings that can be used as a role model from generation to generation. According to Nor Norlaila Bulat [1], whether consciously or not, the teaching profession is a job that demands a teacher to be an example to students. Teachers must be able and skilled to be exemplary in terms of sustainability, personality, height of knowledge, diligence in work as well as practicing noble values that adhere to professionalism in educating and guiding the younger generation. 
According to Nurfatihah [2], to be a prepared teacher, they must be knowledgeable and expert on the subject to be taught. This matter is emphasized so that the teaching and learning journey can be implemented smoothly and can provide benefits and positive changes to students. It is very important for a teacher to convey the correct information in line with the content of this new subject because to make a lesson more meaningful, it requires a teacher's effort and enthusiasm so that students can benefit from his teaching in life. Therefore, the self-readiness of prospective teachers who will face the challenges ahead is very important to be able to convey knowledge in an integrated manner with the activities to be carried out to students.

Therefore, this study was conducted to examine prospective home science teachers on the teaching of design and technology subjects. Based on the Malaysian Curriculum Standards for Design and Technology, teachers must understand the content that will be taught at the secondary level where the content is based on design skills using technology by combining various sub topics into fields of knowledge and skills, namely technical, agricultural technology and home science. This curriculum emphasizes on aspects of basic knowledge and design skills, basic carpentry and technology to enable students to produce high quality products. According to Zaiha Nabila Md Harun [3], this design and technology curriculum is still in the same position to head towards developing students' abilities on technological skills, their creativity and entrepreneurial spirit. These skills are basic skills that can be fully applied to students so that they become more independent and confident and can live a productive life in this world of technology and economy that is always flexible.

\section{Readiness to Teach}

The responsibility of teachers is big where they must be able to instruct in a variety of subjects and reach students with engaging lesson plans where they need to do lot of preparation before lesson. This is the sacrifice of an incomparable teacher to produce a generation that is useful and can provide benefits for religion, nation and country. According to Siti Salwa Sawari and Azlina Mustaffa [4], when the teaching and learning process begins, teachers must be prepared and fully focus to ensure that students' master of each lesson delivered is up to their knowledge to students. Therefore, the readiness of a teacher is very important in order for him to teach so that the knowledge imparted is accurate and can be applied to students until adulthood.

\section{Teacher's Knowledge}

According to Suriana Ismail [5], preparing knowledge in the topics taught is important so that the implementation of learning and teaching can continue well. In this case, the teacher must have knowledge that is in line with the passage of time and always adhere to the given curriculum. In this modern world, there is a great need for teachers who have high integrity to enable them to answer all sorts of problems and doubts that are put forth to them. Therefore, the readiness of teachers to knowledge is very important so that teachers can convey knowledge correctly and can help students in solving a problem they face. Based on a study by Zaiha Nabila Md Harun [6], teachers must have knowledge of all learning content in design and technology subjects. Teachers also need to have sincere knowledge and understanding in each learning topic and be able to relate the content of the lesson clearly. This is due to the subject of design and technology is a subject that gives certainty to the learners in thinking skills and using real experience in their practical classes.

\section{Teacher's Skills}

According to Fathiah Zamani [7], education in modern times does not only depend on knowledge alone but skills for an educator are something that is highly emphasized. With the available skills, a teacher can provide the efficiency and effectiveness of a teaching and learning while conveying knowledge effectively. A teacher who has the skills and knowledge will master the learning and teaching implemented. To master a certain knowledge of skills, prospective teachers need to be exposed to doing various correct ways during practical training and involve all students so that knowledge can be conveyed more effectively. It is very important for prospective teachers to have adequate skills because practical learning involves the use of various science materials and equipment to explain a scientific fact. Science teachers should build skills in guiding students to understand science concepts in their investigations Buxton and Provenzo, [8]. This also applies to science-related topics like agricultural science.

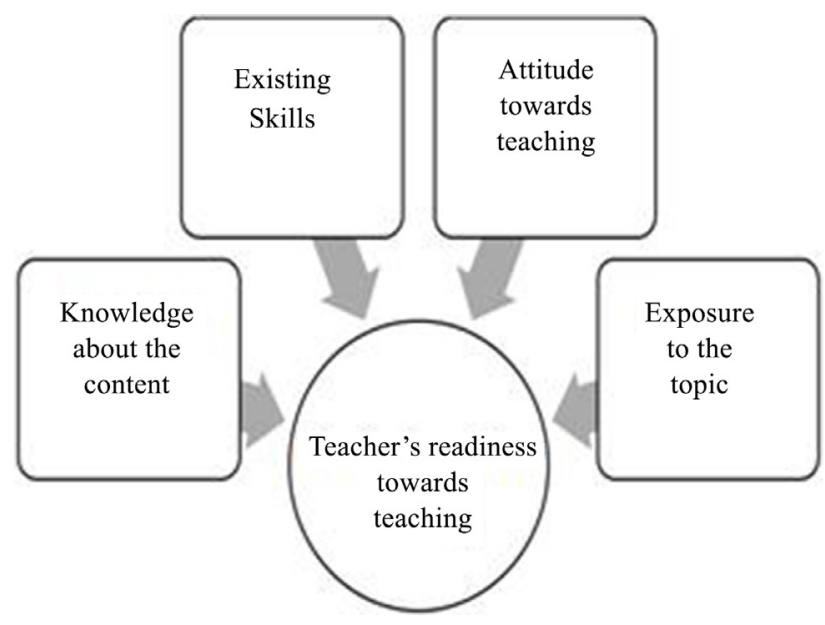

Figure 1. Theoretical framework of teacher readiness 


\section{The Conceptual Framework}

Researchers have proposed a perception model on the level of readiness of prospective teachers to teach alternative agriculture topics based on aspects of prospective teachers' knowledge, existing skills, attitudes towards teaching and exposure of alternative agriculture topics to prospective teachers who will teach design and technology subjects. Figure 1 shows the theoretical framework of teachers' readiness referred in this study. The components researched are important aspects to assess the extent to which prospective teachers are willing to teach design and technology subjects more effectively. The readiness of prospective teachers is very important in the implementation of the curriculum because with the teaching of a capable teacher leads to better understanding about the topic to the students. Therefore, this important aspect should be taken for researchers to study the extent of readiness of prospective home science teachers towards teaching alternative agricultural topics in design and technology subjects in the future.

\section{Method}

\section{Research Design}

The study uses a quantitative method which involves a survey using a questionnaire approach. It is a descriptive study which describes the finding and data collected descriptively, in terms of mean, percentage and frequency values. The results of the collected data can help explain in depth the level of readiness of prospective teachers to teach alternative agricultural topics in design and technology subject. The distribution of the questionnaire was intended to obtain information related to the level of readiness of prospective home science teachers in teaching alternative agricultural topics in design and technology subjects in future secondary schools.

\section{Population and Sampling}

The study conducted by the researcher is a quantitative study. In the use of this quantitative method, Fathiah Zamani [7] said researchers use purposive sampling method where students in years 3 and 4 from Bachelor of Home Science Education from a public university who have taken basic agricultural science subjects as the sample and study population. This population was selected because the researcher wanted to study in depth on the level of readiness to teach among prospective home science teachers whether they are at high, medium or low level, and they are about to enter the teaching profession very soon. The researcher selected the entire population of prospective home science teachers who are in Year 3 and
Year 4, which is a total of 77 people. Due to the small number of prospective teachers who have taken the course, the researcher took the entire population of prospective teachers for this study.

\section{Instrument}

In total, there are a total of 50 question items that examine the level of readiness of prospective home science teachers on the teaching of alternative agricultural topics in design and technology subjects. The questionnaire that the researcher has produced has five sections, namely Section A, B, C, D and Section E. The items of the questionnaire are constructed and modified according to the suitability of the study conducted. Section A is for the demographic and background data of the respondents. Question items for sections B and E of the survey form are based on closed -ended 'yes or no' type questions to obtain correct answers. Whereas, each item of part $\mathrm{C}$ and part $\mathrm{D}$ question section was taken from the survey form based on 5 -point scale $(\mathrm{SD}=$ strongly disagree, $\mathrm{D}=$ disagree, $\mathrm{NS}=$ not sure, $\mathrm{A}=$ agree and $\mathrm{SA}=$ strongly agree) as a research tool to collect information.

\section{Data Collection Procedure}

The data were collected within two hours through distribution to relevant respondents. All respondents were gathered in two classroom sessions and were given a time slot in order to complete their questionnaire. After the time ended, all the completed questionnaires were gathered and collected for further data analysis by the researcher to get the output and findings for the research. It is to take note that since the research was conducted during the pandemic, the sampling size is limited to a smaller group and was gathered via the distribution of questionnaires.

\section{Data Analysis}

The descriptive analysis of the data so obtained was conducted using SPSS software. This study aimed to examine the level of readiness of prospective home science teachers to teach alternative agricultural topics in design and technology subjects.

\section{Results and Discussion}

The analysis of demographic data is shown in table 1. The items were to examine the distribution of gender, age, examination achievement of the relevant subject, year of study, highest qualification and interest in the topic. The results that have been analyzed are as follows: 
Table 1. Analysis on demographic profile of the respondents

\begin{tabular}{ccc}
\hline Factors & Frequency & Percentage \\
\hline \multicolumn{4}{c}{ Gender } \\
Man & 8 & 10.4 \\
Women & 69 & 89.6 \\
\hline \multicolumn{3}{c}{ Years of study } \\
\hline Year 3 & 36 \\
Year 4 & 41 & 46.8 \\
Total & 77 & 53.2 \\
\multicolumn{4}{c}{ Highest Qualification } \\
\hline \multicolumn{4}{c}{ Foundation/ Matriculation } & 44 \\
Sijil Tinggi Persekolahan & 19 & 53.2 \\
Malaysia & 17 & 24.7 \\
Diploma & 77 & 22.1 \\
Total &
\end{tabular}

The Level of Knowledge of Prospective Home Science Teachers on the Teaching of Alternative Agriculture Topic

The first construct of the questionnaire was the questions on the level of knowledge among prospective home science teachers on the teaching of alternative agricultural topics in the subjects of design and technology. To find out the level of knowledge of prospective teachers, researchers have created items meant to test on content mastery of agriculture. The answer was either 'yes' or 'no'. The responses where then marked as right or wrong before being analysed descriptively.

Table 2. Frequency and percentages of responses on content knowledge in agriculture.

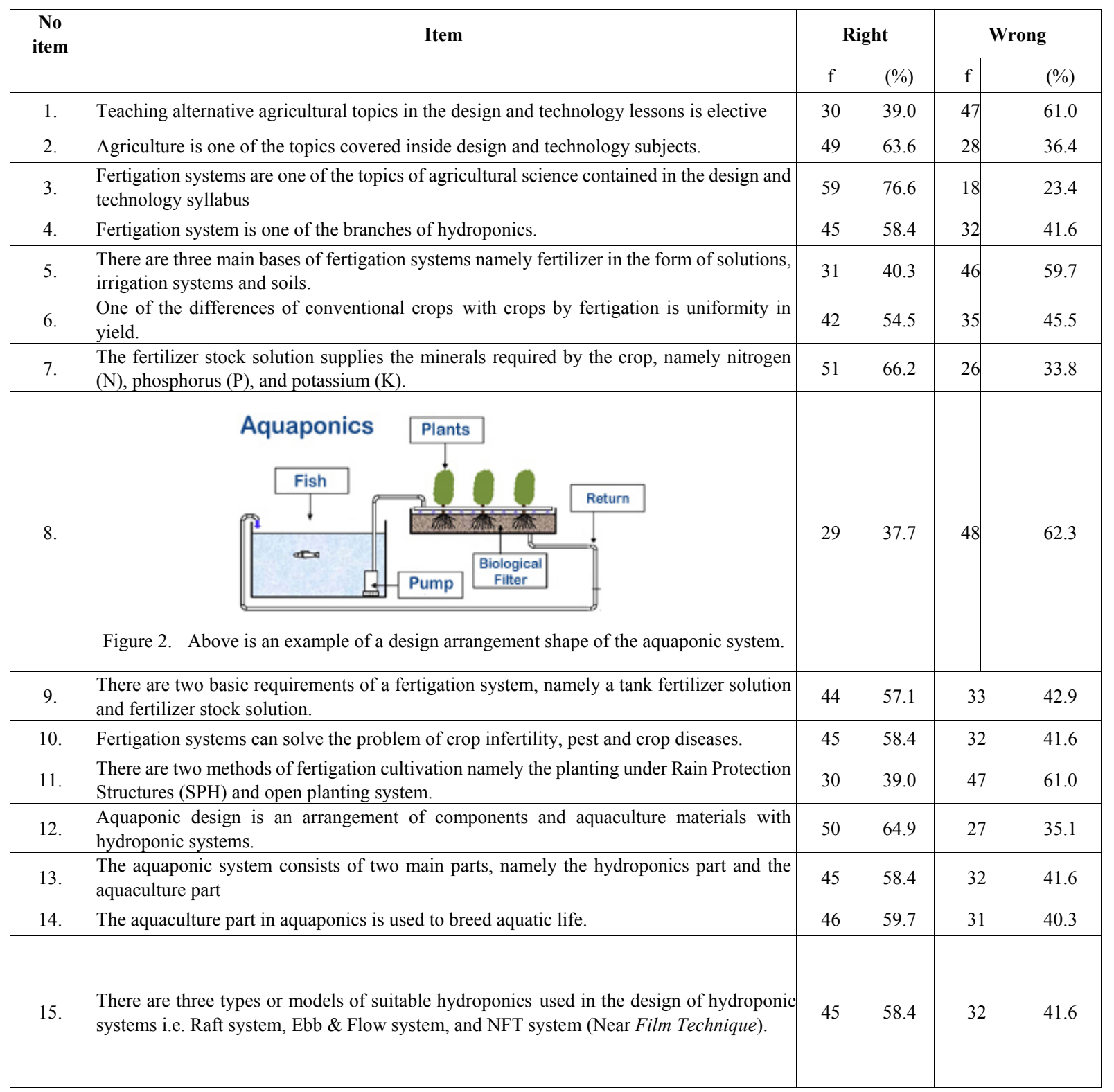


Table 2 Continued

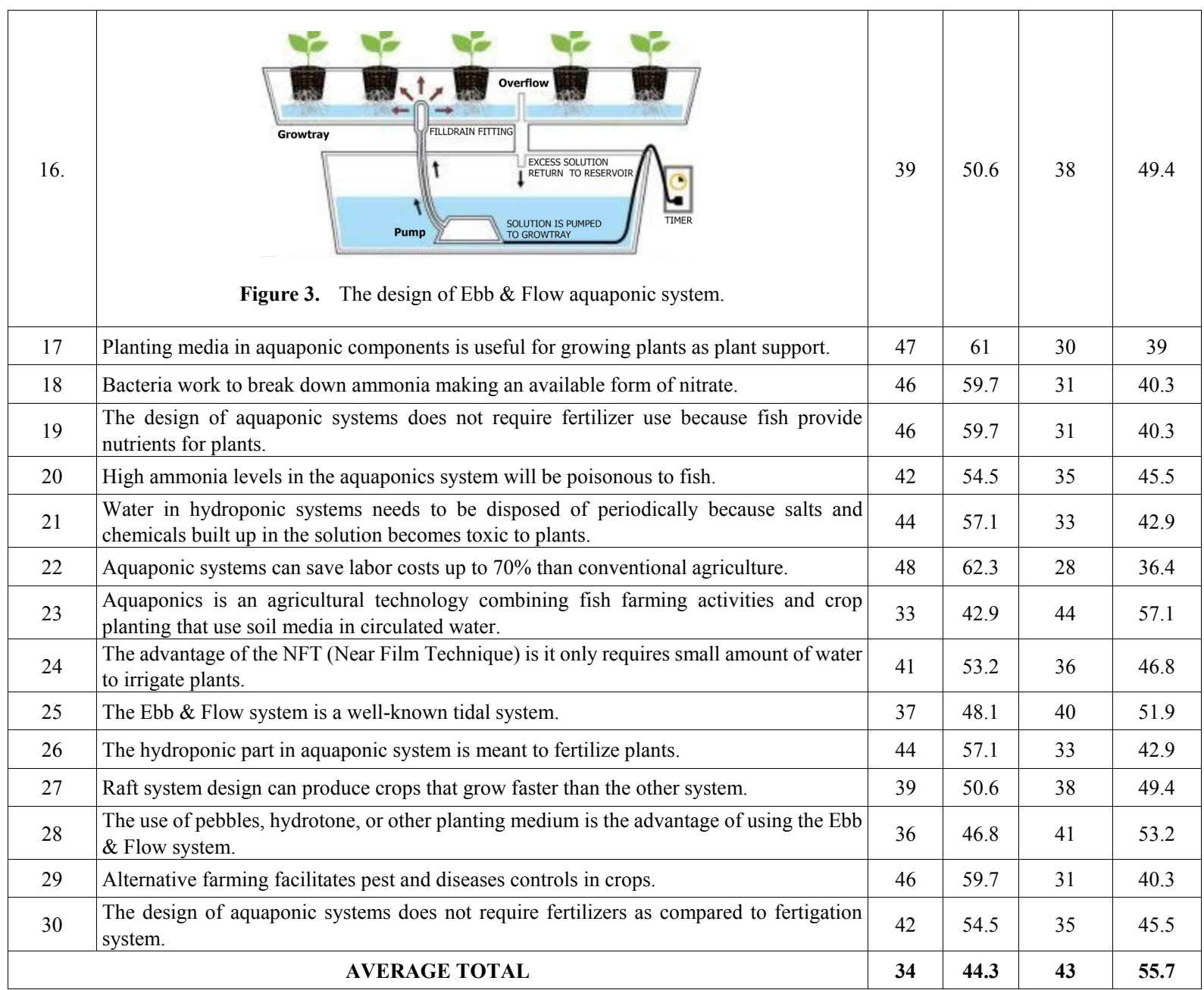

Based on table 2 above, the average number of students who are able to answer all the questions correctly related to the topic of alternative agriculture is 34 people $(44.3 \%)$ while a total of 43 people $(55.7 \%)$ who were not able to answer alternative agriculture topic questions correctly. In the constructed questionnaire, there were 4 negative question items that the researcher had selected to assess the level of knowledge. The question items are in question $1,5,8$ and question 23. It was found that more than half of the respondents did not answer correctly to the question given, namely item 1 as many as 47 people (61\%), item 5 as many as 46 people $(59.7 \%)$, item 8 a total of 48 people $(62.3 \%)$ and item 23 a total of 44 people (57.1\%).
The Level of Exposure of Prospective Home Science Teacher to Teach the Topic of Alternative Agriculture in Design and Technology Subjects

The items in the prospective teacher skill level question were to measure respondents' perceptions of the skills they had in relation to alternative agricultural topics found in design and technology subjects. The table shows the percentage values, frequency, Mean score and standard deviation of each item found in the prospective teacher skills question section. The overall mean is Mean $=3.34$ $(\mathrm{SD}=0.47)$ which shows the skill level of year 3 and year 4 students is at a moderate level. 
Table 3. Skill level of prospective home science teachers

\begin{tabular}{|c|c|c|c|c|c|c|c|c|}
\hline \multirow[t]{2}{*}{ No } & \multirow[t]{2}{*}{ Item } & \multicolumn{5}{|c|}{$\begin{array}{c}\text { Frequency (f) } \\
\text { Percent (\%) }\end{array}$} & \multirow[t]{2}{*}{ Min } & \multirow[t]{2}{*}{$\begin{array}{l}\text { Sideways } \\
\text { standard }\end{array}$} \\
\hline & & $\mathrm{SD}$ & $\mathrm{D}$ & NS & A & $\mathrm{SA}$ & & \\
\hline \multirow{3}{*}{1.} & \multirow{3}{*}{$\begin{array}{l}\text { I master the skill teaching design } \\
\text { subjects form and technology. }\end{array}$} & 0 & 11 & 12 & 48 & 6 & 3.63 & 0.83 \\
\hline & & & & & & & & \\
\hline & & 0 & 14.3 & 15.6 & 62.3 & 7.8 & & \\
\hline \multirow{3}{*}{2.} & \multirow{3}{*}{$\begin{array}{c}\text { I know how to handle equipment and } \\
\text { materials that used in teaching } \\
\text { agricultural science. }\end{array}$} & 0 & 12 & 6 & 50 & 9 & 3.73 & 0.87 \\
\hline & & & & & & & & \\
\hline & & 0 & 15.6 & 7.8 & 64.9 & 11.7 & & \\
\hline \multirow{3}{*}{3.} & \multirow{3}{*}{$\begin{array}{c}\text { I can build a model fertigation design } \\
\text { structure by using various types of } \\
\text { materials. }\end{array}$} & 0 & 14 & 14 & 44 & 5 & 3.52 & 0.87 \\
\hline & & & & & & & & \\
\hline & & 0 & 18.2 & 18.2 & 57.1 & 6.5 & & \\
\hline \multirow{3}{*}{4.} & \multirow{3}{*}{$\begin{array}{c}\text { I'm sure that I am already mastered the } \\
\text { content of agricultural alternatives } \\
\text { topics in design and technology. }\end{array}$} & 1 & 22 & 15 & 34 & 5 & 3.26 & 0.99 \\
\hline & & & & & & & & \\
\hline & & 1.3 & 28.6 & 19.5 & 44.2 & 6.5 & & \\
\hline \multirow{3}{*}{5.} & \multirow{3}{*}{$\begin{array}{c}\text { I understand about elements and } \\
\text { principles in fertigation design system }\end{array}$} & 0 & 11 & 6 & 54 & 6 & 3.71 & 0.81 \\
\hline & & & & & & & & \\
\hline & & 0 & 14.3 & 7.8 & 70.1 & 7.8 & & \\
\hline \multirow{3}{*}{6.} & \multirow{3}{*}{$\begin{array}{c}\text { I have the skills to evaluate design } \\
\text { sketches on new fertigation cultivation }\end{array}$} & 2 & 14 & 7 & 46 & 8 & 3.57 & 0.99 \\
\hline & & & & & & & & \\
\hline & & 2.6 & 18.2 & 9.1 & 59.7 & 10.4 & & \\
\hline \multirow{3}{*}{7.} & \multirow{3}{*}{$\begin{array}{c}\text { I do not control skills to teach } \\
\text { agricultural science with using strategy } \\
\text { effective teaching. }\end{array}$} & 5 & 18 & 11 & 34 & 9 & 3.31 & 1.15 \\
\hline & & & & & & & & \\
\hline & & 6.5 & 23.4 & 14.3 & 44.2 & 11.7 & & \\
\hline \multirow{3}{*}{8.} & \multirow{3}{*}{$\begin{array}{c}\text { I can't relate agricultural science } \\
\text { teaching with design and technology. }\end{array}$} & 2 & 22 & 7 & 37 & 9 & 3.38 & 1.10 \\
\hline & & & & & & & & \\
\hline & & 2.6 & 28.6 & 9.1 & 48.1 & 11.7 & & \\
\hline
\end{tabular}

Referring to table 3 above showing the skill level of prospective home science teachers, a total of $44.2 \%$ which is a total of 34 respondents said "I do not master the skills to teach agricultural science by using effective teaching strategies" This indicates the mean value at medium level. Meanwhile, for the highest Mean is on the second question which is "I know how to handle equipment and materials used in teaching agricultural science." that is, the Mean value showed $3.73(\mathrm{SD}=0.87)$.

Table 4. Mean level distribution

\begin{tabular}{cc}
\hline Min scale & Min level \\
\hline $1.00-2.34$ & Low \\
$2.35-3.67$ & Moderate \\
$3.68-5.00$ & High \\
\hline
\end{tabular}

The attitude of prospective home science teachers at public university towards teaching alternative agricultural topics

Table 5 shows the percentage values, mean frequency and standard deviation for the attitude of prospective teachers of Bachelor of Home Science Education, students towards alternative agriculture topics. The overall mean of the attitude of prospective teachers is high and shows a positive attitude with a value of Mean $=3.78(\mathrm{SD}=0.52$. For the low question that is on item 3 with a value of Mean $=3.71(\mathrm{SD}=1.28)$. Item question 3 is a negative question "I feel the lesson agricultural science does not need to be taught in the design and technology syllabus."

Table 4 further explains how the Min Scale is used to derive the respondent's feedback which includes table 3 , table 5 and table 6 from the questionnaire. 
Table 5. Attitudes of prospective teachers of home science at public university towards the teaching of alternative agriculture topics

\begin{tabular}{|c|c|c|c|c|c|c|c|c|}
\hline \multirow{2}{*}{ No } & \multirow{2}{*}{ Item } & \multicolumn{5}{|c|}{ Frequency Percent (\%) } & \multirow{2}{*}{ Mean } & \multirow{2}{*}{$\begin{array}{l}\text { Standard } \\
\text { deviation }\end{array}$} \\
\hline & & SD & $\mathrm{D}$ & A & NS & SA & & \\
\hline 1 & $\begin{array}{l}\text { I am ready to accept challenges in the career } \\
\text { I'm involved }\end{array}$ & $\begin{array}{l}0 \\
0\end{array}$ & $\begin{array}{l}4 \\
5.2\end{array}$ & 3 & $\begin{array}{l}51 \\
66.2\end{array}$ & $\begin{array}{c}19 \\
24.7\end{array}$ & 4.10 & 0.70 \\
\hline 2 & $\begin{array}{l}\text { I'm willing to make additional readings to } \\
\text { improve knowledge related to agricultural } \\
\text { technology }\end{array}$ & 1 & $\begin{array}{c}6 \\
7.8\end{array}$ & 5.2 & $\begin{array}{l}43 \\
55.8\end{array}$ & $\begin{array}{c}23 \\
29.9\end{array}$ & 4.05 & 0.89 \\
\hline 3 & $\begin{array}{l}\text { I feel the lesson agricultural science does not } \\
\text { need to be teach in the design and technology } \\
\text { syllabus }\end{array}$ & $\begin{array}{l}4 \\
5.2 \\
\end{array}$ & $\begin{array}{r}16 \\
20.8 \\
\end{array}$ & $\begin{array}{c}4 \\
5.2 \\
\end{array}$ & $\begin{array}{r}27 \\
35.1 \\
\end{array}$ & $\begin{array}{r}26 \\
33.8 \\
\end{array}$ & & \\
\hline 4 & $\begin{array}{l}\text { For me teaching agriculture science is very } \\
\text { important because agriculture is the main } \\
\text { source of income for the country. }\end{array}$ & $\begin{array}{l}7 \\
9.1\end{array}$ & 3 & $\begin{array}{l}39 \\
50.6\end{array}$ & 28 & 28 & 4.14 & 0.87 \\
\hline 5 & $\begin{array}{l}\text { I am aware the importance of teaching } \\
\text { agriculture in design and technology } \\
\text { subjects so I will encourage students to } \\
\text { create a new design related to agriculture. }\end{array}$ & $\begin{array}{l}0 \\
0\end{array}$ & $\begin{array}{c}4 \\
5.2\end{array}$ & 2.6 & $\begin{array}{r}46 \\
59.7\end{array}$ & $\begin{array}{l}25 \\
32.5\end{array}$ & 4.19 & 0.73 \\
\hline 6 & $\begin{array}{l}\text { I always follow the latest development of } \\
\text { design and technology in agricultural so it } \\
\text { will be easier to teach the topic }\end{array}$ & $\begin{array}{l}0 \\
0\end{array}$ & $\begin{array}{r}9 \\
11.7 \\
\end{array}$ & $\begin{array}{r}14 \\
18.2 \\
\end{array}$ & $\begin{array}{c}39 \\
50.6 \\
\end{array}$ & $\begin{array}{c}15 \\
19.5 \\
\end{array}$ & 3.78 & 0.90 \\
\hline 7 & $\begin{array}{l}\text { I'm confident in my abilities being a teacher } \\
\text { and facilitators to students in teaching the } \\
\text { latest designing agricultural technology. }\end{array}$ & 0 & 9.1 & $\begin{array}{c}8 \\
10.4\end{array}$ & 69 & $\begin{array}{c}13 \\
16.9\end{array}$ & 3.88 & 0.79 \\
\hline
\end{tabular}

Table 6. Level of exposure of prospective home science teachers

\begin{tabular}{|c|c|c|c|c|c|}
\hline \multirow{2}{*}{ No } & \multirow{2}{*}{ Item } & \multicolumn{2}{|c|}{ Yes } & \multicolumn{2}{|c|}{ No } \\
\hline & & $f$ & $\%$ & $f$ & $\%$ \\
\hline 1 & $\begin{array}{l}\text { The lecturer gives exposure agriculture activity while } \\
\text { studying theory and practice }\end{array}$ & 75 & 97.4 & 2 & 2.6 \\
\hline 2 & $\begin{array}{l}\text { Lecturers use a variety of teaching methods to increase } \\
\text { students' knowledge in design and technology agriculture }\end{array}$ & 74 & 96.1 & 3 & 3.9 \\
\hline 3 & $\begin{array}{l}\text { Lecturers share experiences related to agricultural } \\
\text { activities available locally or abroad. }\end{array}$ & 74 & 96.1 & 3 & 3.9 \\
\hline 4 & $\begin{array}{l}\text { I got relevant information regarding agricultural design } \\
\text { and technology on the internet, posters and from other } \\
\text { source }\end{array}$ & 73 & 94.8 & 4 & 5.2 \\
\hline 5 & I attended a seminar related on agricultural. & 68 & 88.3 & 9 & 11.7 \\
\hline & TOTAL & & 94.54 & & 5.46 \\
\hline
\end{tabular}

Level of Exposure of Prospective Teachers of Home Science at Public University to Teach Agricultural Topics Alternatives in Design and Technology Subjects

Based on table 6, the results can be analysed that the respondents of the questionnaire show a high level of exposure of prospective teachers to the topic of alternative agriculture. Percentage of respondents agreed in item 1 "Lecturers gave me exposure to agricultural activities during theoretical and practical learning." is $97.4 \%$ while the lowest level of exposure is on question item 5 "I have attended seminars or visits related to agriculture." that is, only $88.3 \%$ gained knowledge about agriculture in agriculture -related seminars or visits.

\section{Conclusions}

The results of this research show the level of readiness of prospective home science teachers has a moderate level of readiness towards the teaching of alternative agricultural topics in the subjects of design and technology. The teaching of these prospective teachers needs to be improved through the knowledge aspect of the content that will be taught because the findings of the study found that the level of knowledge of prospective teachers is at a low level. According to Hafizan Suhairi [9], content knowledge is a structure that can describe the field of understanding of educators on the subject of teaching in the classroom. This understanding includes the educators' strategies that they use in specific teaching, skills in teaching topics and attitudes of prospective teachers as well as increased exposure to the field of knowledge they are involved in. Although prospective teachers in this study have been exposed to the knowledge imparted at their level of study, but the level of knowledge of prospective teachers is still at a low level. This may be due to their lack of emphasis on the topic of alternative agriculture in the implementation of the program 
curriculum. Thus, educators must equip themselves by diversifying methods through teaching skills before implementing teaching and learning so that the teacher's teaching gets more attention from students and obtains effectiveness in teaching the subjects taught.

\section{Recommendations}

In producing a perfect teaching and learning, a teacher must have complete knowledge of a field of knowledge. However, the school that accepts the new prospective teachers should be guided so that they can perform the tasks given perfectly even if the prospective teachers are not from among the teachers who have options in the field. By implementing courses or programs that are suitable for prospective teachers will be able to provide a way for them to be able to understand more deeply about his career as a teacher. Therefore, prospective teachers must always be prepared in many things, including being prepared from the physical, mental, emotional and attitude aspects of the teacher.

This study only focused on Year 3 and Year 4 students who were only conducted at public university. For further studies and suggestion to fulfil the research gap,

1. The researcher suggested that further study be continued by conducting a study on the factors that influence the readiness of final year students towards the teaching of topics found in design and technology subjects in other Universities or educational institution and that have a field of education.

2. The researcher suggested to conduct a survey to teachers of design and technology subjects in schools on problems in learning and teaching related to design and technology and how teachers overcome problems in order to see the extent of effectiveness and competence of teachers on teaching them effectively.

\section{REFERENCES}

[1] Norlaila Bulat and Abu, Baharin (2006). Tahap Kesediaan Kemahiran Dan Pengetahuan Pedagogi Guru Guru Pkpg Kh Dalam Pengajaran Dan Pembelajaran Mata Pelajaran Kemahiran. Journal of Technical \& Vocational Education, Living Skills

[2] Nurfathiah Abdul Ghani (2018). Faktor-faktor yang berkaitan dengan tekad keusahawanan pertanian pelajar pra-siswazah pendidikan sains pertanian. Tesis Bacelor Pendidikan. Journal of Social Sciences (Volume 2, No. 4, 2014, Pages 133 to 138 )

[3] Zaiha Nabila Md Harun (2014), Kompetensi Guru Dalam Pengajaran Amali Reka Bentukdan Teknologi Di Sekolah Rendah Daerah Batu Pahat.

[4] Siti Salwa Md. Sawari \& Azlina Mustaffa (2014). Guru Bersahsiah Mulia Menurut Pandang Ibnu Sahnun: Analisa Buku Adab Al Mualimin. The Online Journal of Islamic Education. Journal of Social Sciences Vol. 2 Issue 2.

[5] Suriana Ismail (2012). Kesediaan Guru Terhadap Pelaksanaan Mata Pelajaran Reka Bentuk Dan Teknologi (RBT) Sekolah Rendah Di Malaysia. Tesis Ijazah Sarjana Pendidikan Teknik dan Vokasional. Universiti Tun Hussein Onn Malaysia. Journal Pendidikan Teknik dan Vokasional.

[6] Zaiha Nabila Md Harun (2014), Kompetensi Guru Dalam Pengajaran Amali Reka Bentukdan Teknologi Di Sekolah Rendah Daerah Batu Pahat.

[7] Fathiah Zamani (2007). Tahap Penguasaan Kemahiran Manipulatif Di Kalangan Guru Pelatih Kimia Universiti Teknologi Malaysia. Journal of Science \& Mathematics Education. pp (1-9).

[8] Buxton, Cory A., Provenzo, Eugene F, Jr (2007). Teaching Science in Elementary \& Middle School: A Cognitive and Cultural Approach. SAGE Publications, $2^{\text {nd }}$ edition.

[9] Hafizan Mohd Suhairi dan Anuar Ahmad (2017). Pengaruh pengetahuan isi kandungan terhadap aplikasi pengajaran yang berkesan dalam kalangan guru-guru sejarah. Malay Language Education Journal. 2180-4842. Vol. 10, Bil.2 